\title{
Quality Management in Higher Education: Review and Perspectives
}

\author{
Anastasia Papanthymou ${ }^{1} \&$ Maria Darra ${ }^{1}$ \\ ${ }^{1}$ Department of Primary Education, University of the Aegean, Rhodes, Greece \\ Correspondence: Anastasia Papanthymou, Department of Primary Education, University of the Aegean, \\ Dimokratias 1, Rhodes, 85132, Greece. Tel: 30-694-833-9499. E-mail: premnt15043@rhodes.aegean.gr
}

Received: July 12, 2017

doi:10.5539/hes.v7n3p132
Accepted: July 24, 2017

Online Published: August 13, 2017

URL: http://doi.org/10.5539/hes.v7n3p132

\begin{abstract}
This paper is a review which presents a summary of 52 studies from 2006 to 2016 in Quality Management (QM) within Higher Education Institutes (HEIs). The aim of this paper is to submit evidence regarding the level of QM in HEIs, particularly in developing countries, and also to enhance the research in the field of QM. The findings reveal that from 2013 onward there is an increased interest in the items of QM mainly in Arabic countries. Moreover, the findings include Critical Success Factors (CSFs), obstacles and benefits that confirm and supplement previous literature. The type (private or public) and age of university, transformational leadership, integration, respect of a person, character, constructive conflict, creative tension, enthusiasm, awareness and orientation of employees and faculty and resource allocation are CSFs that this study reveals. Also, infrastructure limitations focused on human and financial capital, limited involvement of stakeholders and measurement of a complex range of performance indicators are barriers which enrich the analysis. Moreover, the extra benefits of QM practices are that QM is appropriate to the purpose of HEIs, meets the expectations and the new roles of HEIs, and lastly, the implementation of QM practices can solve problems and propose solutions.
\end{abstract}

Keywords: benefits, Critical Success Factors (CSFs), Higher Education (HE), obstacles, Quality Management (QM)

\section{Introduction}

Quality has a variety of definitions and a broad concept. For some, quality is linked to the meaning of superiority and excellence, and to others quality is an assurance that there are fewer services or products with defects. Quality is otherwise linked to product features (Alzhrani, Alotibie, \& Abdulaziz, 2016). The majority of these definitions focus on customers and their satisfaction (Takalo, Abadi, Vesal, Mizaei, \& Nawaser, 2013).

According to Green (1994) quality is a great and exciting challenge to Higher Education (HE). Providing quality services from Higher Education Institutions is the key to differentiate between competitors as well as ensuring sustainability for a long period (Govender, Veerasamy, \& Noel, 2014). According to Nadim and Al-Hinai (2016), quality in education is a very vital issue because HEIs are accountable to several stakeholders such as students, society and other. Also, quality of HE is one of the most significant aspects of the creation of knowledge, human resource development and social force for any country. According to Becket and Brooks (2008) in many countries and many cultures the issue of Quality Management has been steadily on the agenda of HEIs. The issues of QM have become one of the most basic ingredients and strengths within HEIs all over the world (Ganguly, 2015). This study underlines the issues that influence the successful implementation of QM such as obstacles to QM implementation, CSFs and of course the benefits that HEIs have from it. This is necessary because knowledge of these drives to improvement of QM.

One of the most known QM models that has been implemented in HE is Total Quality Management (TQM). TQM is a philosophy and system for continuously improving the services offered to customers (Al-Tarawneh \& Mubaslat, 2011). A lot of reports have documented the advantages of adopting TQM in HEIs (Tsinidou, Gerogiannis, \& Fitsilis, 2010). In addition to that model there are also others that will be presented in this study and have been implemented from HEIs in various countries specifically in Arabic and developing countries.

\subsection{Significance of the Study}

According to Tarí and Dick (2016), there are few studies provide a literature review in the field of QM mainly in $\mathrm{HE}$ and there are gaps in the following issues: a) obstacles to QM, b) drivers for successful implementation of QM practices or Critical Success Factors, c) quality models that are used by HEIs, and d) benefits of QM 
practices. Consequently, there is a need for providing information in order to improve QM in HEIs. The contribution of this study is to offer evidence from the area of QM in HEIs and provide useful information to countries that want to implement QM. The aim of this study is to summarize, analyze and give feedback on the recent studies on QM in HE in different countries over the last decade (2006 to 2016).

\section{Literature Review}

\subsection{Obstacles to QM Implementation}

The major barriers or obstacles to successful implementation of QM such as TQM are presented in the following table (Yarahmadi \& Magd, 2016).

Table 1. Obstacles to successful QM implementation

\begin{tabular}{l}
\hline Obstacles to QM \\
\hline 1. Lack of management commitment \\
2. Poor Vision and Plan Statement \\
3. The Government Influence \\
4. A lack of highly qualified professionals \\
5. Lack of knowledge about the self-assessment mechanisms \\
6. Resistance of institutional assessment/change \\
7. Poor coordination between employees and departments \\
8. Lack of interest in training \\
9. Expectation of immediate results \\
10. Instability of leaders and departments \\
11. Rigid organizational structures \\
12. Lack of clarity about role and responsibilities \\
13. Lack of employees' commitment
\end{tabular}

Source: Yarahmadi and Magd (2016).

\subsection{CSFs of QM Implementation}

According to In'airat and Al-Kassem (2014) CSFs are the significant fields of exercise that have to be carried out well in order for an organization to accomplish its target. The knowledge of CSFs is vital in order to improve QM practices such as TQM (Zakuan et al., 2012).

In the field of CSFs, Black and Porter (1996) compare factor models that are important for an organization to successfully implement TQM models. The results are shown in the following table.

Table 2. Comparison of factor models

\begin{tabular}{ll}
\hline Saraph et al.: & Black and Porter: \\
Saraph's 8 factors model & Critical Factors of TQM \\
\hline
\end{tabular}




\begin{tabular}{ll}
\hline Top Management & Corporate Quality Culture \\
Leadership & $\begin{array}{l}\text { Strategic Quality Management } \\
\text { Quality Improvement Measurement }\end{array}$ \\
Quality Data and Reporting & Systems \\
Training & People and Customer Management \\
Employee Relations & Operational Quality Planning \\
Process Management & External Interface Management \\
Product/Service Design & Supplier Partnerships \\
Supplier $\quad$ Quality & Teamwork Structures \\
Management & Customer Satisfaction Orientation \\
Role of the Quality & Communication of Improvement \\
Department & Information \\
\hline
\end{tabular}

Source: Black and Porter (1996).

CSFs such as teamwork, leadership and management commitment, communication, continuous improvement, employee involvement, total customer satisfaction and training positively influence the HEIs performance (Zakuan et al., 2012).

According to Sharma, Gupta and Singh (2014) there are six required critical factors for a suitable implementation of TQM: commitment, culture, continuous improvement, cooperation, customer focus and control. Al-Omoush, Alrahahleh, and Alabaddi (2015) study the core concept of the following CSFs: Customer focus, continuous improvement, employee involvement and administrative leadership.

According to several studies in Arabic countries, there are seven CSFs to a successful TQM (Pushpa, 2016): vision and plan statement, employee involvement, customer focus, reward and recognition, education and training, commitment of top management and quality management supplier.

\subsection{Quality Management Models That Have Been Implemented in HEIs}

Several Quality Management Models that have been developed for using in the industry have been implemented in HEIs all over the world. Globally, the tool that is the most usually drawn upon is TQM (Becket \& Brookes, 2008).

Table 3. Quality Management Models in HEIs

\begin{tabular}{ll}
\hline \multicolumn{1}{c}{ Model } & \multicolumn{1}{c}{ Definition } \\
\hline TQM & $\begin{array}{l}\text { A comprehensive management approach which requires contribution from all participants in the } \\
\text { organization to work towards long-term benefits for those involved and society as a whole. }\end{array}$ \\
EFQM excellence & $\begin{array}{l}\text { Non-prescriptive framework that establishes nine criteria (divided between enablers and results), } \\
\text { suitable for any organization to use to assess progress towards excellence. }\end{array}$ \\
Balanced scorecard & $\begin{array}{l}\text { Performance/strategic management system which utilizes four measurement perspectives: financial; } \\
\text { customer; internal process; and learning and growth. }\end{array}$ \\
Malcolm Baldridge & $\begin{array}{l}\text { Based on a framework of performance excellence which can be used by organizations to improve } \\
\text { performance. Seven categories of criteria: leadership; strategic planning; customer and market focus; } \\
\text { measurement, analysis, and knowledge management; human resource focus; process management; } \\
\text { and results. }\end{array}$ \\
& $\begin{array}{l}\text { International standard for generic quality assurance systems. Concerned with continuous } \\
\text { improvement through preventative action. Elements are customer quality and regulatory } \\
\text { requirements, and efforts made to enhance customer satisfaction and achieve continuous } \\
\text { improvement. }\end{array}$ \\
\hline
\end{tabular}




\begin{tabular}{ll}
\hline $\begin{array}{l}\text { Business } \\
\text { processre-engineerin }\end{array}$ & $\begin{array}{l}\text { System to enable redesign of business processes, systems and structures to achieve improved } \\
\text { performance. It is concerned with change in five components: strategy; processes; technology; } \\
\text { organization; and culture. }\end{array}$ \\
SERVQUAL & $\begin{array}{l}\text { Instrument designed to measure consumer perceptions and expectations regarding quality of service } \\
\text { in five dimensions: reliability; tangibles; responsiveness; assurance and empathy; and to identify } \\
\text { where gaps exist. }\end{array}$ \\
\hline
\end{tabular}

Source: Becket and Brookes (2008).

\subsection{Benefits of QM Implementation}

QM models such as TQM can help an educational institution provide more qualitative services to its primary customers (Farooq, Akhtar, Ullah, \& Memon, 2007).

Important benefits of TQM adoption are: increased employee confidence, continuous development, better quality from the customer's viewpoint, bridge of faculty-staff's functions and better teamwork (Ali \& Shastri, 2010).

According to Todorut (2013), benefits of TQM implementation also include: innovation, financial potential, opportunities of innovation, better control of processes in the design, planning, distribution field, bigger flexibility, high quality services and strength of the position on the market.

TQM has been exceedingly acknowledged and successfully implemented in many organizations, providing them with the advantage in international and in local markets through the creation of high quality services or products to satisfy the needs of the customers (Zakuan et al., 2012; In'airat \& Al-Kassem, 2014).

Table 4. Summary of previous research that shows the importance and the benefits of QM

\begin{tabular}{|c|c|c|c|c|}
\hline Authors & Title & & Findings & Location \\
\hline $\begin{array}{l}\text { Jiju Antony et } \\
\text { al. (2002) }\end{array}$ & $\begin{array}{l}\text { Success factors of TQM } \\
\text { implementation in the } \\
\text { industry and industry-Hong } \\
\text { Kong. }\end{array}$ & $\square$ & $\begin{array}{l}\text { Factors that influence the success } \\
\text { of TQM implementation in } \\
\text { organizations in Hong Kong is a } \\
\text { commitment of management, the } \\
\text { role of quality department, training } \\
\text { and education, employee } \\
\text { involvement, continuous } \\
\text { improvement. } \\
\text { A close relationship with suppliers, } \\
\text { product design and service, quality } \\
\text { policy, quality of data and reports, } \\
\text { communications and customer } \\
\text { satisfaction orientation. }\end{array}$ & Hong Kong \\
\hline $\begin{array}{l}\text { Mile Terziovski } \\
\text { and Danny } \\
\text { Samson (1999) }\end{array}$ & $\begin{array}{l}\text { The relationship between } \\
\text { implementation of TQM } \\
\text { practices with organizational } \\
\text { performance in various } \\
\text { sectors and organization } \\
\text { sizes. }\end{array}$ & $\square$ & $\begin{array}{l}\text { TQM has a positive relationship to } \\
\text { performance and business } \\
\text { operations, employee relations and } \\
\text { customer satisfaction. }\end{array}$ & Various sectors \\
\hline $\begin{array}{l}\text { Bishnu Sharma } \\
\text { and David } \\
\text { Gadenne (2001) }\end{array}$ & $\begin{array}{l}\text { Importance and } \\
\text { effectiveness of quality } \\
\text { management approach. }\end{array}$ & $\square$ & $\begin{array}{l}\text { Many business firms in Australia } \\
\text { implemented ISO } 9000 \text { and TQM } \\
\text { in maintaining the quality level of } \\
\text { production and services. }\end{array}$ & $\begin{array}{l}\text { Business firms in } \\
\text { Australia }\end{array}$ \\
\hline
\end{tabular}




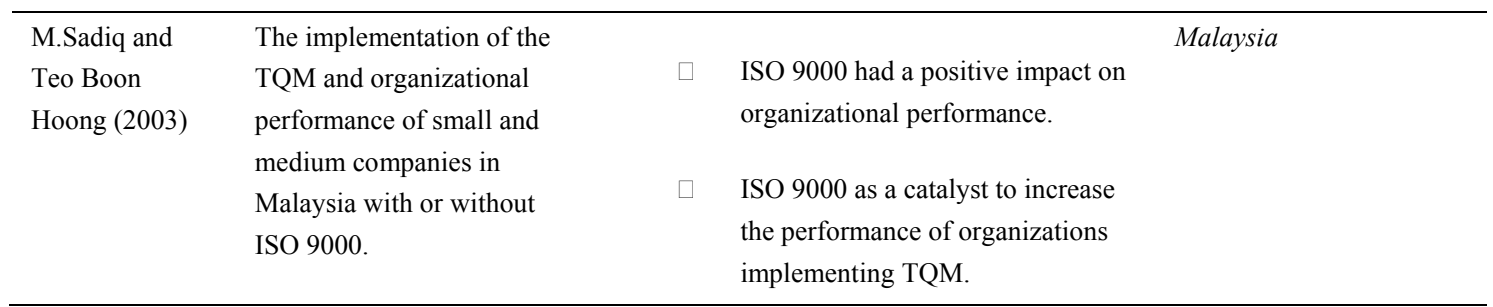

Source: Zakuan et al. (2012).

According to Zabadi (2013), there are potential benefits from TQM adoption such as maintenance competitiveness, emphasis on the market needs, elimination of inefficiencies, satisfaction of the demands of stakeholders, reduction of the cost of performance, increase of production capacity, high level of service quality excellence and high level in all areas of an organization.

\section{Research Questions}

This study aims to provide answers to the following research questions:

1) What are the most common topics in the studies we examine?

2) What are the methods that are used?

3) What are the countries that contribute to research of QM in HEIs?

4) What are the obstacles to QM practices?

5) What are the CSFs of QM practices?

6) What are the QM models or practices that have been implemented in HEIs?

7) What are the benefits of QM practices?

We examine articles in research journals of education, management and proceedings papers and we provide answers about the most discussed QM items, the countries that have contributed to research and the methods that have been used.

Also, the paper outlines literature on the following four issues: a) the obstacles to QM in various areas, b) the Critical Success Factors, c) the quality models or practices that have been implemented by HEIs, and d) the benefits of QM adoption. This paper summarizes studies that have empirically investigated the previous four issues in the specific area of HEIs over the last decade (2006 to 2016), presents and discusses the results. Moreover, suggest gaps and directions for future research in the field of QM within HE.

\section{Method}

We selected articles, from educational and business journals and proceedings papers that have been published in the last decade (2006-2016) in the field of QM in HEIs. We particularly used the following search machines and databases: Emerald insight, Taylor \& Francis Online, Science Direct, ERIC Institute of Education Science, Google Scholar, Macrothink Institute Online Journals, Research Gate, Canadian Center of Science and Education (CCSE), European Journal of Social Sciences Education and Research (EJSER), European American Journals (EAJ), International Journal of Applied Sciences and Management of Applied Sciences (IJASM) of Waljat College, Journal of Efficiency and Responsibility in Education and Science (ERIESJOURNAL) of the Faculty of Economics and Management Czech, University of Life Sciences Prague and Human Resource Management Academic Research Society (HRMARS). In total, the searches yielded 112 articles and proceedings papers. Firstly, we read the articles of journals and the proceedings papers and we clearly concluded that were met the aims of the study (Tarí \& Dick, 2016). We proceeded to create 8 topics and categorized them according to each individual topic. One article or proceedings paper may be relevant to more than one topic. We were left with 52 articles and proceedings papers in total, with the remaining 59 not fulfilling the criteria and were excluded. Excel was used to record data according to year, topic, type of journal, proceedings paper, methods and country. We then developed tables and figures to summarize and present this data. Empirical studies were selected and analytical tables developed to provide a summary and presentation of the obstacles to $\mathrm{QM}$, the CSFs, the QM practices and the benefits of QM. 


\section{Results}

52 studies were analyzed. The majority of which are in education articles $(52 \%, \mathrm{~N}=27)$ followed by the studies in business articles $(37 \%, \mathrm{~N}=19)$ and in proceedings papers $(12 \%, \mathrm{~N}=6)$. From that sample, the empirical studies are $(75 \%, \mathrm{~N}=39)$ and the theoretical $(25 \%, \mathrm{~N}=13)$.

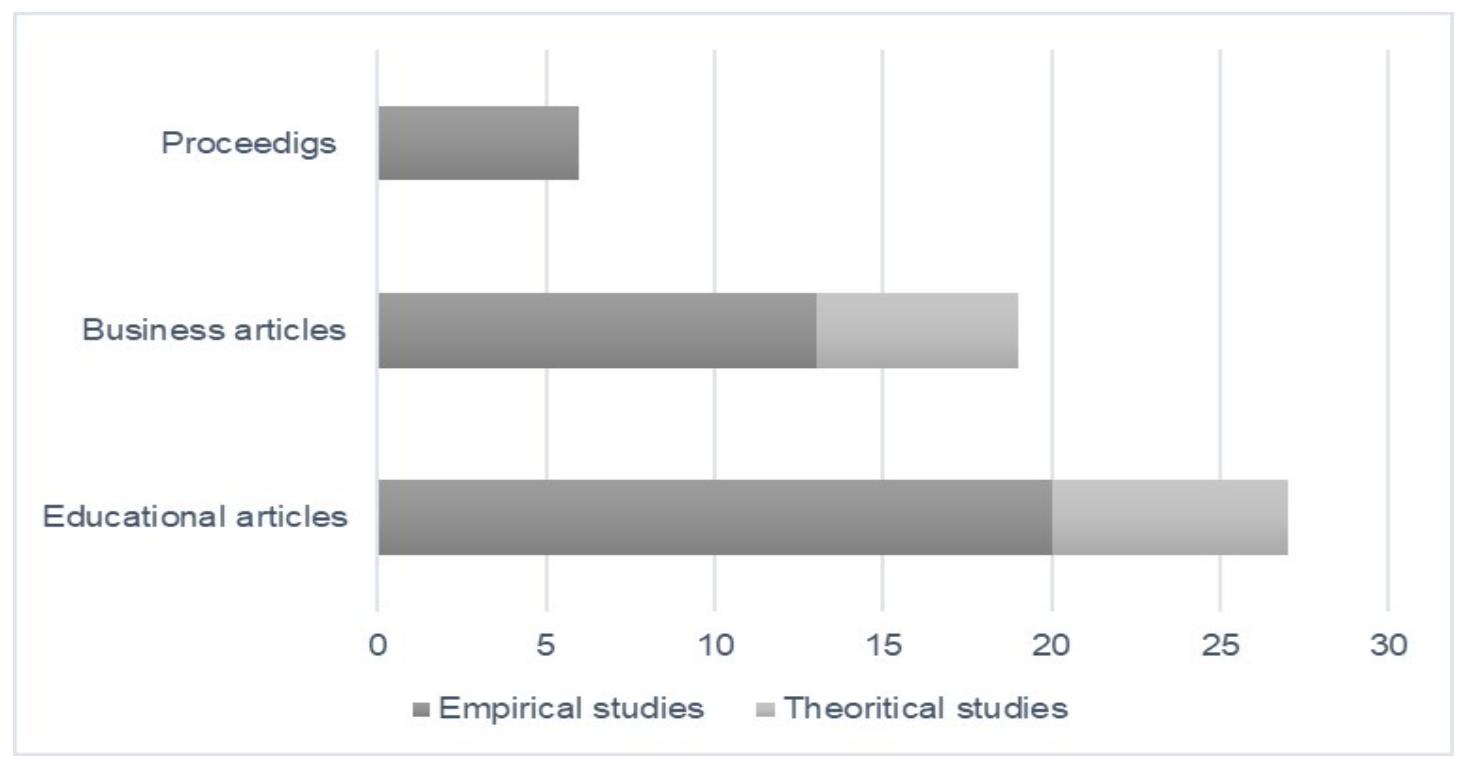

Figure 1. Number of education, business articles and proceedings papers on the research

We analyzed articles and proceedings papers from 2006 to 2016. Most of them have been published in recent years. This confirms that there is an increased interest in the items of QM in HEIs.

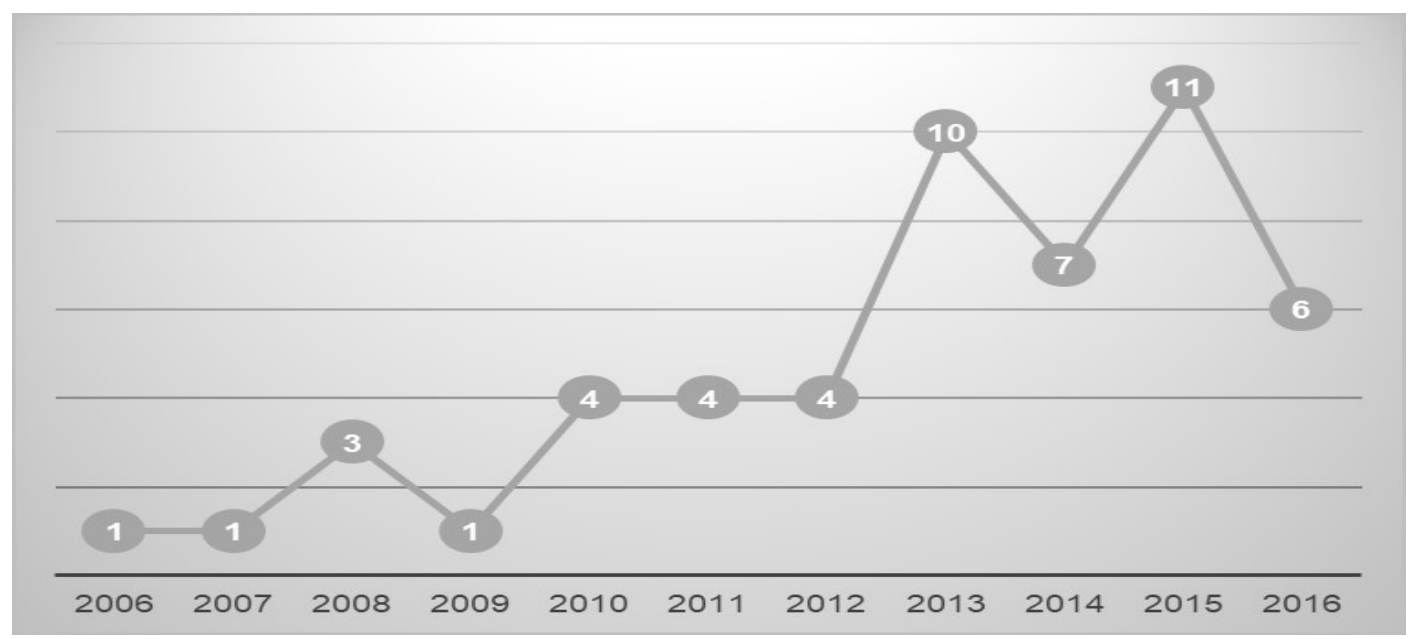

Figure 2. Number of studies of QM in HEIs per year from 2006 to 2016

\subsection{The Most Common Topics in the Articles and Proceedings Papers}

The most common topics that have been discussed are the "QM models or practices" (31.6\%), followed by the "Implementation of QM models" (19.7\%), the "CSFs of QM" (15.8\%) and the "Benefits of implementing QM models" (13.2\%). The fact that journals of education focus more on "QM models or practices" $(28.9 \%)$, "Implementation of QM models" (18.4\%), and less on "Quality dimensions" (7.9\%) confirm the results of the research of Tarí and Dick (2016). 
Table 5. Topics of QM in HEIs in business, education articles and proceedings papers

\begin{tabular}{|c|c|c|c|c|c|c|c|c|c|c|c|c|c|c|}
\hline \multirow{2}{*}{ Topics in studies } & \multicolumn{3}{|c|}{ Theoretical } & \multicolumn{3}{|c|}{ Empirical } & \multicolumn{4}{|c|}{ Total } & \multicolumn{3}{|c|}{ Percentage } & \multirow[b]{2}{*}{ Total } \\
\hline & $\mathrm{B}$ & $\mathrm{E}$ & $\mathrm{P}$ & B & $\mathrm{E}$ & $\mathrm{P}$ & B & E & $P$ & Total & $\mathrm{B}$ & $\mathrm{E}$ & $\mathrm{P}$ & \\
\hline Implementation of QM models & 4 & 4 & & 4 & 3 & & 8 & 7 & & 15 & 27.6 & 18.4 & 0.0 & 19.7 \\
\hline QM models or practices & 1 & 2 & & 7 & 9 & 5 & 8 & 11 & 5 & 24 & 27.6 & 28.9 & 55.6 & 31.6 \\
\hline CSFs of QM & 2 & 2 & & 3 & 5 & & 5 & 7 & & 12 & 17.2 & 18.4 & 0.0 & 15.8 \\
\hline Obstacles to QM models & 1 & 1 & & & 2 & 1 & 1 & 3 & 1 & 5 & 3.4 & 7.9 & 11.1 & 6.6 \\
\hline Quality dimensions of services & 2 & 1 & & 1 & 2 & & 3 & 3 & & 6 & 10.3 & 7.9 & 0.0 & 7.9 \\
\hline Definition of stakeholder & 1 & 1 & & & & & 1 & 1 & & 2 & 3.4 & 2.6 & 0.0 & 2.6 \\
\hline $\begin{array}{l}\text { Factors influence stakeholder's } \\
\text { satisfaction }\end{array}$ & & & & & 2 & & & 2 & & 2 & 0.0 & 5.3 & 0.0 & 2.6 \\
\hline \multirow{2}{*}{$\begin{array}{l}\text { Benefits of implementing QM } \\
\text { models }\end{array}$} & 1 & 3 & & 2 & 1 & 3 & 3 & 4 & 3 & 10 & 10.3 & 10.5 & 33.3 & 13.2 \\
\hline & 12 & 14 & 0 & 17 & 24 & 9 & 29 & 38 & 9 & 76 & 100 & 100 & 100 & 100 \\
\hline
\end{tabular}

Note. $(\mathrm{B})=$ Business article; $(\mathrm{E})=$ Education article; $(\mathrm{P})=$ Proceedings Paper.

\subsection{Methods That Are Used}

We classified the studies into Theoretical and Empirical. The most used method is empirical, though we notice an increasing tendency of theoretical methods and a reduced tendency for empirical methods after 2015. It is concluded therefore that there is a need for more empirical studies in several fields of QM in HEIs. Tarí and Dick (2016) notice knowledge gaps and suggest future empirical studies to investigate topics such as the "Obstacles to QM", the "Critical Success Factors for QM", the "QM models that have been used by HEIs", the "Benefits of QM adoption" and others.

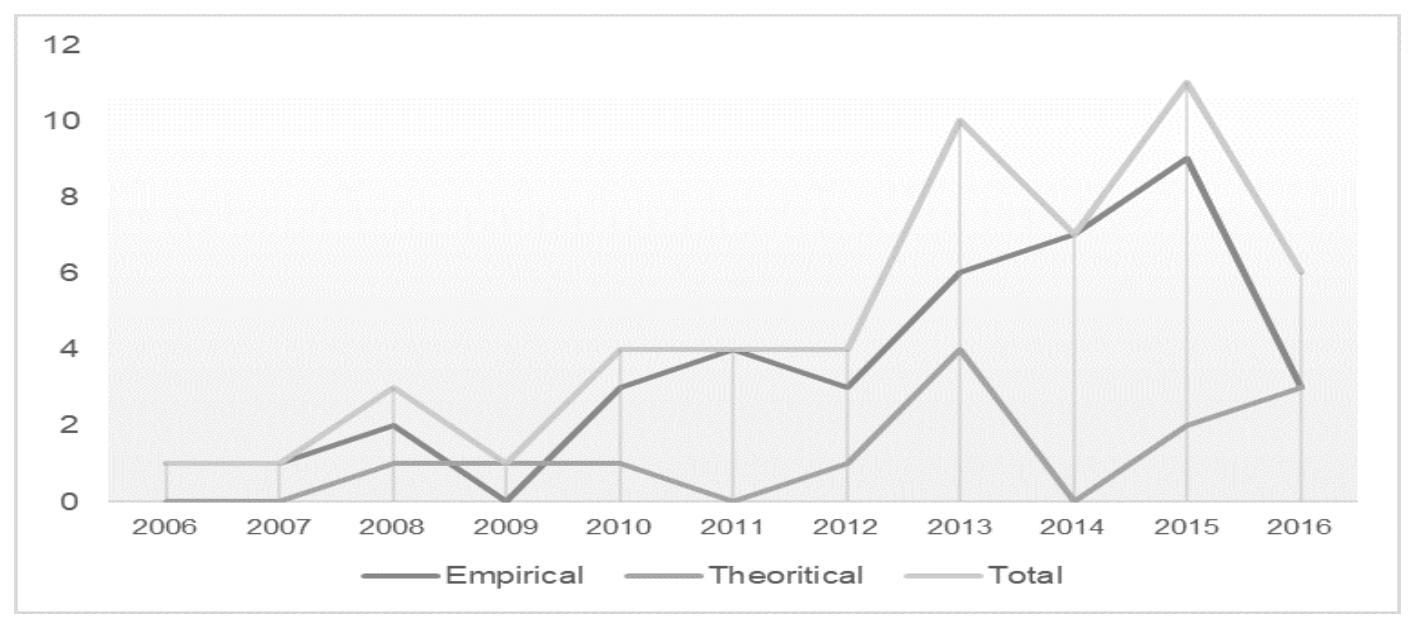

Figure 3. Methods are used in studies of QM in HE from 2006 to 2016

\subsection{Countries That Contribute to Research of QM in HEIs the Last Decade from 2006 to 2016}

We examined empirical studies from 23 different countries. Many of those countries try to adopt QM in HEIs or have recently adopted the QM practices. As we can see from the diagram below, 13 countries (representing 57\% of examined countries) that are in the list of developing countries according to the data of International Statistic Institute (2017) such as Albania, Ghana, Jordan, Kenya, Libya, Macedonia Fyr., Malaysia, Mauritius, Nigeria, Pakistan, South Africa, Turkey and Zimbabwe are making attempts in the field of QM in HEIs. Quality services is an important issue for HEIs all over the world in order to respond to a demanding and ever-changing 
environment in the area of HE (Nyaoga, Nyamwange, Onger, \& Ombati, 2010). Service quality is a vital strategy for survival and success in an antagonistic environment (Anim \& Mensah, 2015).

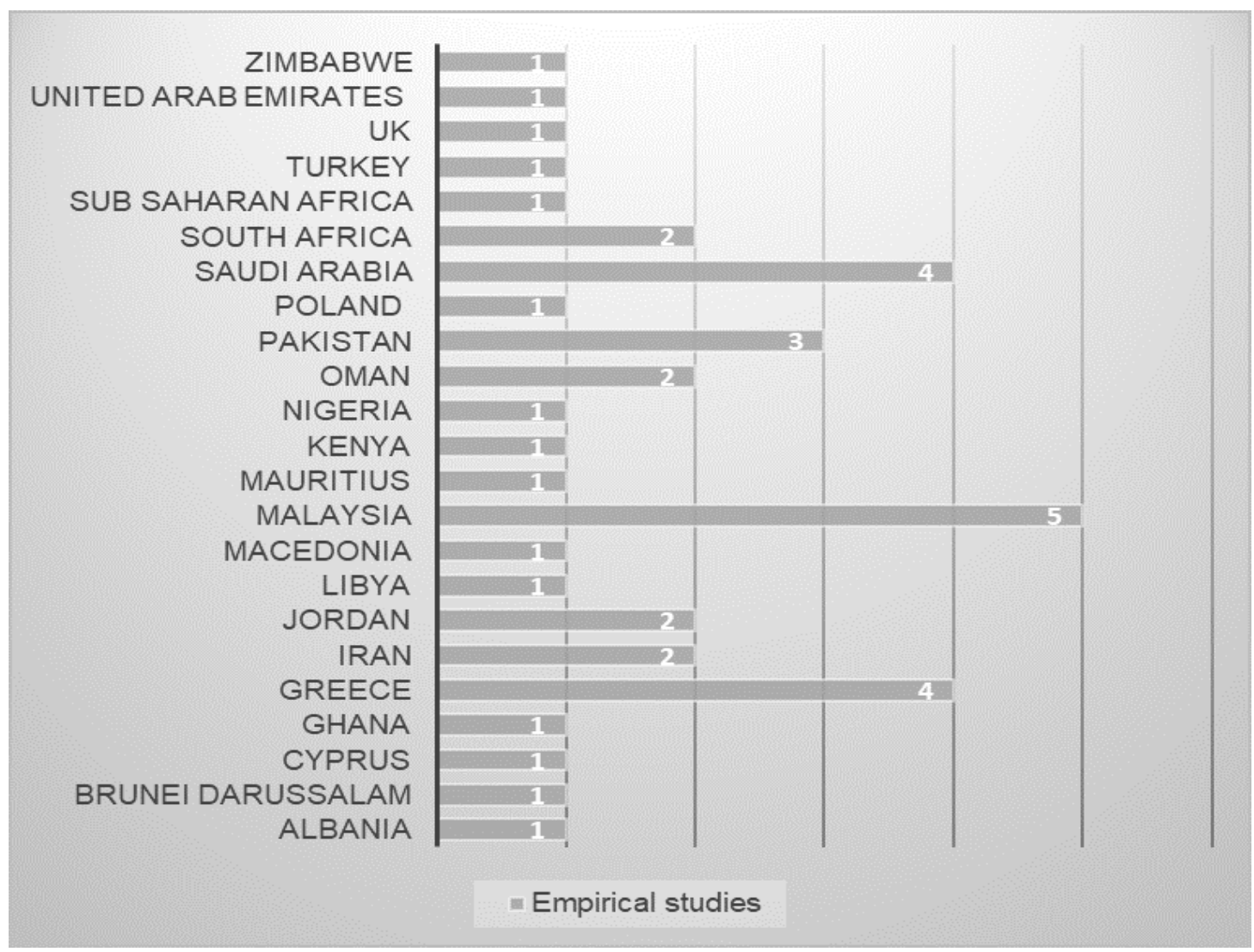

Figure 4. A number of empirical studies of QM in HE in 23 countries

\subsection{Obstacles to QM Practices}

The following table summarizes and presents the obstacles that countries we examined face during the implementation of QM practices.

Table 6. Obstacles to QM practices that HEIs of examining countries have faced

\begin{tabular}{llc}
\hline \multicolumn{1}{c}{ Researchers (Year) } & \multicolumn{1}{c}{ Obstacles } & Country \\
\hline $\begin{array}{l}\text { 1. Arrif, Zaidin, \& Sulong } \\
\text { (2007) }\end{array}$ & $\begin{array}{l}\text { Measurement of a complex range of performance indicators such as } \\
\text { performance, program specification, process outputs, quality of graduates, } \\
\text { service standard }\end{array}$ & Malaysia \\
& Limited involvement of stakeholders & Turkey \\
2. Yalcin (2012) & Communication obstacles faced by teaching staff & Saudi \\
3. Albaqami (2015) & Faculty resistance & Arabia \\
\hline
\end{tabular}

Faculty resistance and communication obstacles support the study of Yarahmadi and Magd (2016). This review based on Table 6 reveals also the following obstacles:

- Limited involvement of stakeholders

- Infrastructure limitations focused on human and financial capital 
- Measurement of a complex range of performance indicators

\subsection{CSFs of QM Practices}

The following table summarizes and presents the factors that are critical to the successful implementation of QM practices.

Table 7. CSFs of QM practices that HEIs of examining countries have noticed

\begin{tabular}{|c|c|c|}
\hline Researchers (Year) & CSFs & Country \\
\hline 1. Davies (2008) & Integration & United Kingdom \\
\hline \multirow{7}{*}{$\begin{array}{l}\text { 2. Asif, Awan, Khan and Ahmad } \\
\text { (2013) }\end{array}$} & Leadership & Pakistan \\
\hline & Vision & \\
\hline & Program design & \\
\hline & Resource allocation & \\
\hline & Measurement and evaluation & \\
\hline & Process control improvement & \\
\hline & Other stakeholders & \\
\hline 3. Argia and Ismail (2013) & Transformational leadership & Libya \\
\hline \multirow[t]{7}{*}{ 4. Taskov and Mitreva (2014) } & Teamwork & Macedonia \\
\hline & Respect of a person, character & \\
\hline & Experience & \\
\hline & Knowledge & \\
\hline & Constructive conflict & \\
\hline & Creative tension & \\
\hline & Enthusiasm & \\
\hline \multirow[t]{8}{*}{ 5. Albaqami (2015) } & $\begin{array}{l}\text { Awareness of the university's commitment to maintain high quality } \\
\text { standard }\end{array}$ & Saudi Arabia \\
\hline & Commitment of management & \\
\hline & Support of leadership & \\
\hline & Awareness and orientation of employees and faculty & \\
\hline & Staff's background and qualification & \\
\hline & The age of a university & \\
\hline & The type of university (private or public) & \\
\hline & Involvement of stakeholders & \\
\hline 6. Garvwe (2015) & Student involvement & Zimbabwe \\
\hline \multirow[t]{2}{*}{ 7. Farooq et al. (2007) } & Commitment of university's administration or management & Brunei \\
\hline & & Darussalam \\
\hline \multirow[t]{3}{*}{ 8. Nadim and Al-Hinai (2016) } & Employee involvement & Oman \\
\hline & Focus on students & \\
\hline & Focus on other stakeholders & \\
\hline
\end{tabular}

In comparison, with the previous analysis, customer focus is an important critical success factor that is confirmed by previous research (Sharma et al., 2014; Al-Omoush et al., 2015; Pushpa, 2016) and in this study customers are the students and the other stakeholders. Apart from employee involvement (Zakuan et al., 2012; Al-Omoush et al., 2015; Pushpa, 2016) in this study the involvement of stakeholders and student involvement were also noted. Control (Sharma et al., 2014) in this study indicates process control improvement. Leadership and management 
commitment (Zakuan et al., 2012) is also one more CSF that is noticed. Product or service design (Black \& Porter, 1996) is indicated as a program design. Training (Black \& Porter, 1996; Zakuan et al., 2012; Pushpa, 2016) and education (Pushpa, 2016) in this study is indicative of staff's background, qualification, experience and knowledge. Teamwork (Black \& Porter, 1996) and vision (Pushpa, 2016) are also CSFs that are confirmed in this study. Quality improvement measurement systems (Black \& Porter, 1996) are connected to measurement and evaluation that have also been noted in this study. Apart from the previous CSFs, this study also reveals the following factors that can supplement the literature in each individual field:

- $\quad$ Age and the type of university (private or public)

- Transformational leadership

- Integration

- Respect of a person or character

- Constructive conflict

- Creative tension

- $\quad$ Enthusiasm

- Awareness and orientation of employees and faculty

- Resource allocation

5.6 QM Practices or Models That Have Been Implemented in HEIs

The following table summarizes and presents the QM practices in HEIs which were examined.

Table 8. QM practices or models that HEIs of countries have implemented

\begin{tabular}{|c|c|c|}
\hline Researchers (Year) & QM models or practices & Country \\
\hline 1. Abdullah (2006) & $\begin{array}{l}\text { Higher Education Performance-Service Performance } \\
\text { (HEdPERF-SERVPERF) }\end{array}$ & Malaysia \\
\hline 2. Zafiropoulos and Vrana (2008) & Service Quality (SERVQUAL) & Greece \\
\hline 3. Manola and Tsarouhas (2010) & Failure Mode and Effects Analysis (FMEA) & Greece \\
\hline 4. Tsinidou et al. (2010) & Analytical Hierarchical Process (AHP Method) & Greece \\
\hline 5. B. Khodayari and F. Khodayari (2011) & Service Quality (SERVQUAL) & Iran \\
\hline 6. Al-Tarawneh and Mubaslat (2011) & Total Quality Management (TQM) & Jordan \\
\hline 7. Chalaris and Poustourli (2012) & Balance Scorecard Technique & Greece \\
\hline 8. Antoniadou and Chatzipanagiotou (2012) & EFQM Excellence Model & Cyprus \\
\hline $\begin{array}{l}\text { 9. Noaman, Ragab, Fayoumi, Khedra and } \\
\text { Madbouly (2013) }\end{array}$ & $\begin{array}{l}\text { Higher Education Quality Assessment Model } \\
\text { (HEGAM) }\end{array}$ & Saudi Arabia \\
\hline 10. Takalo et al. (2013) & Fuzzy Failure Analysis (FMEA in Fuzzy Environment) & Iran \\
\hline 11. Govender et al. (2014) & Service Quality (SERVQUAL) & South Africa \\
\hline $\begin{array}{l}\text { 12. Stasiak-Betlejewska, Kaye, Dyason, } \\
\text { Stachová and Urbancová (2014) }\end{array}$ & Service Quality (SERVQUAL) & Poland \\
\hline 13. Çerri (2014) & Electronic Service Quality scale (E-S-Qual scale) & Albania \\
\hline 14. Green (2014) & Service Quality (SERVQUAL) & South Africa \\
\hline 15. Anim and Mensah (2015) & Service Quality (SERVQUAL) & $\begin{array}{c}\text { Sub Saharan } \\
\text { Africa }\end{array}$ \\
\hline $\begin{array}{l}\text { 16. Svensson, Antony, Ba-Essa, Bakhsh and } \\
\text { Albliwi (2015) }\end{array}$ & Lean Six Sigma (LSS) & Saudi Arabia \\
\hline 17. Randheer (2015) & $\begin{array}{l}\text { Culture-HEdPERF, HedPERF, SERVPERF } \\
\text { (CUL-HEdPERF, HEdPERF, SERVPERF) }\end{array}$ & Saudi Arabia \\
\hline 18. Twaissi and Al-Kilani (2015) & Service Quality (SERVQUAL) & Jordan \\
\hline
\end{tabular}




\begin{tabular}{llc}
\hline 19. Anwowie, Amoako and Abrefa (2015) & Service Quality (SERVQUAL) & Ghana \\
20. Al-Bashir (2016) & Quality Function Deployment (QFD) & United Arab \\
& Emirates \\
21. Teeroovengadum, Kamalanabhan and & $\begin{array}{l}\text { Higher Education Service Quality-Hierarchical Model } \\
\text { Seebaluck (2016) }\end{array}$ & Mauritius \\
\hline
\end{tabular}

QM practices or models such as SERVQUAL, TQM, EFQM and Balance Scorecard Technique (Becket \& Brookes, 2008) have been implemented also in the HEIs we examined. Apart from these three models, this study presents other techniques and new models that have been implemented in the last years from 2006 to 2016 in HEIs.

- HEdPERF-SERVPERF

- FMEA

- $\quad$ FMEA in Fuzzy Environment

- $\quad$ AHP

- HEGAM

- $\quad$ E-S-Qual scale

- LSS

- $\quad$ CUL-HEdPERF, HEdPERF, SERVPERF

- QFD

- HESQUAL

According to the data in Table 8 , the most usual model for measuring service quality is SERVQUAL (representing $38 \%$ of models). It is noticeable that universities have developed models such as HEGAM, HESQUAL and AHP based on their needs and targets or have adjusted already existing models to their demands and expectations. SERVPERF was modified to measure the quality of services in HE and the model HEdPERF evolved (Randheer, 2015). CUL-HedPERF is a result of adding Arab cultural aspects of the scale of HEdPerf (Randheer, 2015). Nowadays universities are complex organizations and for that reason business procedures are required, such as Lean Six Sigma to facilitate their functions (Svensson et al., 2015).

Also, techniques that are used in industry to promote quality of products, such as FMEA are used to evaluate the educational service quality (Takalo et al., 2013). As a lot of universities implement web-based services (Çerri, 2014), it is necessary that are measured appropriately. The E-S-Qual scale and the HEGAM which includes the criteria of e-services are efforts to that effect. Other models such as AHP method aims to discover the quality of determinants that influence most satisfaction of students. Finally, QFD model identifies the characteristics that must be improved to meet the expectations of stakeholders (Al-Bashir, 2016).

\subsection{Benefits of QM Practices}

The following table summarizes and presents the benefits of QM practices in several countries.

Table 9. Benefits of QM practices that HEIs of examining countries have confirmed and revealed

\begin{tabular}{lll}
\hline \multicolumn{1}{c}{ Researchers (Year) } & \multicolumn{1}{c}{ Benefits } & Country \\
\hline 1. Nyaoga et al. (2010) & QM is appropriate to the purpose of the University of Nairobi & Kenya \\
$\begin{array}{l}\text { 2. Manola and Tsarouhas } \\
\text { (2010) }\end{array}$ & $\begin{array}{l}\text { TQM and its tools are applicable and extremely useful in HE. The implementation of them } \\
\text { can solve problems and propose solutions }\end{array}$ & Greece \\
3. Chalaris and Poustourli & Implementation of balanced scorecard had an advantage on Department of Informatics of & Greece \\
(2012) & Athens over other HEIs in responding to the limited funding and meeting the expectations \\
& and the new roles of HE & Cyprus \\
4. Antoniadou and & Model TQM and EFQM tool were the key to improve quality within European University & Nigeria \\
Chatzipanagiotou (2012) & Cyprus & \\
5. Oluseye, Borishade, & QM has important effects on perceived corporate picture & \\
Adeniyi and Chinelo (2014) & &
\end{tabular}


6. Svensson et al. (2015)

Improvement of quality services (Farooq et al., 2007; Ali \& Shastri, 2010; Zakuan et al., 2012; Todorut, 2013; Zabadi, 2013; In'airat \& Al-Kassem, 2014), more efficient operations and improvement (Zakuan et al., 2012; Todorut, 2013; Zabadi, 2013) and perceived corporate picture (Zakuan et al., 2012) are some benefits which are confirmed in this study. Moreover, the advantage over other organizations (Zakuan et al., 2012; Zabadi, 2013; In'airat \& Al-Kassem, 2014) is an important positive result of QM practices that in this study was referred to as an advantage over other HEIs in responding to the limited funding.

Apart from the similarities which have been revealed in the area of benefits by this study, also presented are extra benefits that can enhance the literature.

Especially:

- $\mathrm{QM}$ is appropriate to the purpose of HEIs

- QM meets the expectations and the new roles of HE

- The implementation of QM practices can solve problems and propose solutions

\section{Discussion}

This study examined previous research in HEIs in journals of education, management and in proceedings papers in the last decade from 2006 to 2016. Predominantly were examined the obstacles to QM practices, the factors that are important for successful implementation of QM practices and the benefits that HEIs have from the implementation of QM. This study also presents the models or practices that have been implemented from HEIs in various countries. It is important to know that most of them (57\%) are developing countries.

In particular, 23 countries were studied. In recent years, mainly from 2013 onward there is an increased interest in the items of QM in HEIs. It is important that many countries, most of them Arabic and developing make an important effort to adopt QM practices and to see the benefits of such implementations. The number of studies in journals of education, management and proceedings papers that were collected shows that the HEIs of most countries are starting to demonstrate interest in providing quality services are operating efficiently in order to survive and succeed in an antagonistic environment (Anim \& Mensah, 2015). The Success of HEIs depends on strategy of management and on how react to an effective practice (Pushpa, 2016).

There are QM models or practices from the area of industry such as FMEA, others from the business area such as LSS and other models that have been developed from HEIs such as HESQUAL, HEGAM and AHP. The most common model that has been implemented by HEIs is SERVQUAL (representing $38 \%$ of models).

Key factors for adopting QM practices are the benefits that a university can gain such as improvement of quality and business processes, better perceived corporate picture, more efficient operation, solution of problems and advantage over other HEIs. Consequently, QM is appropriate to the purpose of a Higher Education Institute.

In the field of CSFs, it was noted that integration, age of university, type of university, transformational leadership, respect of a person, character, experience, program design, resource allocation, student involvement, vision, knowledge, constructive conflict, creative tension and enthusiasm were all factors for successful QM into HEIs.

With regard to obstacles, it was seen that the measurement of complex indicators, the communication obstacles faced by teaching staff, the limited involvement of stakeholders and the infrastructure limitations were mostly on human and financial capital.

Finally, it is necessary to state that the most usual items of QM are "QM models or practices", "Implementation of QM practices", and "CSFs of QM". Items such as the "Definition of stakeholder" and the "Factors that influence stakeholder's satisfaction" have not been discussed in detail. The methods that are used in the studies we examined are more empirical than theoretical. According to Tarí and Dick (2016), there is a need for more empirical studies on the issues of QM. Thus, that is encouraging evidence in the area of QM in HEIs, despite the fact that we noticed a reduced tendency for empirical studies after 2015.

\section{Conclusion}

This study offers evidence from the area of QM in HEIs and provides useful information to countries that want to implement QM concerning the critical factors that influence the successful implementation of it, the obstacles that may face of its implementation, the possible practices that can adopt and the benefits that can reap. The 
results that identify the benefits of QM also can encourage other developing countries to think about QM to improve the quality of their HEIs, which is important for their survival in an antagonistic environment. Countries that follow the example of other countries and having knowledge of basic issues of QM can plan better their strategy for achieving improvement. The fact that the review reveals new obstacles, CSFs, benefits and practices that enhances literature in the field of QM shows that there is plenty of knowledge we can improve on this subject as more and more new countries that don't belong in West and they are developing make an effort to adopt to QM practices in their HEIs.

The limitation of this study was to examine a few studies from each country. Further research concerning each individual country is recommended. This would assist HEIs of each country to develop models to increase their quality of services. Therefore, in comparison with other institutions they would firstly have an advantage in their own particular country and secondly, internationally.

In addition, literature needs more proposed QM models that could be adopted from HEIs all over the world. It is imperative also that these models be adjusted to the culture and other vital factors of a country. Every country approaches the quality in HEIs from different cultural aspects (Soomro \& Ahmad, 2012). The model CUL-HEdPERF which Randheer (2015) developed is an example. This means that we must pay attention to the factors that are important for successful implementation of QM. Consequently, further research in the area of CSFs would be useful and very valuable. Moreover, a comparison between west and other developing countries around the world in the field of QM in HEIs would be interesting.

Both journals of education, management and proceedings papers should cover issues of QM at the same level. As a result, more studies in the area of the "Factors that influence stakeholder's satisfaction" and on "Definition of stakeholder" should be useful.

In conclusion, as developing countries have similar problems, face similar obstacles and conditions, therefore, more empirical studies in these countries would be necessary.

\section{References}

Abdullah, F. (2006). Measuring service quality in higher education: Three instruments compared. International Journal of Research \& Method in Education, 29(1), 71-89. https://doi.org/10.1080/01406720500537445

Albaqami, S. (2015). Implementing Quality Assurance in Saudi Arabia: A Comparison between the MESO and the MICRO Levels at PSU. Higher Education Studies, 5(3), 66-81. https://doi.org/10.5539/hes.v5n3p66

Al-Bashir, A. (2016). Applying Total Quality Management Tools Using QFD at Higher Education Institutions in Gulf Area (Case Study: ALHOSN University). International Journal of Production Management and Engineering, 4(2), 87-98. https://doi.org/10.4995/ijpme.2016.4599

Ali, M., \& Shastri, R. K. (2010). Implementation of total quality management in higher education. Asian Journal of Business Management, 2(1). Retrieved from http://maxwellsci.com/print/ajbm/v2-9-16.pdf

Al-Omoush, M. M., Alrahahleh, A. H., \& Alabaddi, Z. A. (2015). Total Quality Management in Higher Education. Information and Knowledge Management, 5(12). Retrieved from http://www.iiste.org/Journals/index.php/IKM/article/view/27810

Al-Tarawneh, H. A., \& Mubaslat, M. M. (2011). The Implementation of Total Quality Management (TQM) On the Higher Educational Sector in Jordan. International Journal of Industrial Marketing, 1(1). Retrieved from http://sinche.uom.gr/sites/default/files/771-5488-2-pb.pdf

Alzhrani, K. M., Alotibie, B. A., \& Abdulaziz, A. (2016). Total Quality Management in Saudi Higher Education. International Journal of Computer Applications, 135(4), 6-12. https://doi.org/10.5120/ijca2016908245

Anim, S. K., \& Mensah, J. (2015). Service Quality in Higher Education: A Comparative Study in Tertiary Institutions in Sub Saharan Africa. Global Journal of Educational Studies, 1(2). Retrieved from http://www.macrothink.org/journal/index.php/gjes/article/view/7965

Antoniadou, A., \& Hatzipanayiotou, P. (2012). Total Quality Management in Tertiary Educational Institute of Cyprus: A case study. In A. Alexopoulos, C. Koutroumanos, \& A. Trilianos (Eds.), Proceedings of the 2012 National Conference on Quality in Education: Trends and Perspectives (pp. 632-641). Athens, Greece: National and Kapodistrian University of Athens.

Anwowie, S., Amoako, J., \& Abrefa, A. A. (2015). Assessment of Student's Satisfaction of Service Quality in Takoradi Polytechinc: The Students' Perspective. Journal of Education and Practice, 6(29). Retrieved from http://files.eric.ed.gov/fulltextEJ1081276.pdf 
Argia, H. A., \& Ismail, A. (2013). The Influence of Transformational Leadership on the Level of TQM Implementation in the Higher Education Sector. Higher Education Studies, 3(1), 136-146. https://doi.org/10.5539/hes.v3n1p136

Arrif, M. S. M., Zaidin, N., \& Sulong, N. (2007). Total Quality Management Implementation in Higher Education: Concerns and Challenges Faced by the Faculty. Paper presented at the Twelfth International Conference on ISO9000 and TQM, Taiwan, Republic of China. Abstract retrieved from http://bm.nsysu.edu.tw/tutorial/iylu/12th\%20ICIT/07-03.pdf

Asif, M., Awan, M. U., Khan, M. K., \& Ahmad, N. (2013). A model for total quality management in Higher education. Quality \& Quantity, 47(4), 1883-1904. https://doi.org/10.1007/s11135-011-9632-9

Becket, N., \& Brookes, M. (2008). Quality Management Practice in Higher Education-What Quality Are We Actually Enhancing? Journal of Hospitality, Leisure, Sport and Tourism Education, 7(1), 40-54. https://doi.org/10.3794/johlste.71.174

Black, S. A., \& Porter, L. J. (1996). Identification of the critical factors of TQM. Decision sciences, 27(1). https://doi.org/10.1111/j.1540-5915.1996.tb00841.x

Cerri, S. (2014). Electronic service quality in higher education: Evidence from Albania. European Journal of Social Sciences Education and Research, 2(1). https://doi.org/10.26417/ejser.v2i1.p205-211

Chalaris, I., \& Poustourli, C. (2012). Total quality management in higher education with balance scorecard technique. Paper presented at the 2012 Conference of International Business and Economics Systems (MIBES), Larissa, Greece. Abstract retrieved from http://mibes.teilar.gr/proceedings/2012/oral/Chalaris-Poustourli.pdf

Davies, J. (2008). Integration: Is it the key to effective implementation of the EFQM Excellence Model? International Journal of Quality \& Reliability Management, 25(4), 383-399. https://doi.org/10.1108/02656710810865267

Farooq, M. S., Akhtar, M. S., Ullah, S. Z., \& Memon, R. A. (2007). Application of Total Quality Management in Education. Journal of Quality and Technology Management, 3(2). Retrieved from http://files.eric.ed.gov/fulltext/ED506778.pdf

Ganguly, A. (2015). Exploring Total Quality Management (TQM) Approaches in Higher Education Institutions in a Globalized Environment-Case Analysis of UK and Sweden. British Journal of Education, 3(7). Retrieved from http://www.eajournals.org/wp-content/uploads/Exploring-Total-Quality-Management-TQM-Approaches-in -Higher-Education-Institutions-in-a-Globalized-Environment-Case-Analysis-of-UK-and-Sweden.pdf

Garvwe, E. C. (2015). The Impact of Involving Students in Managing the Quality of Higher Education Provision. Journal of Education and Training Studies, 3(2), 51-60.

Govender, J. P., Veerasamy, D., \& Noel, D. T. (2014). The service quality experience of International students: The case of a selected higher education institution in South Africa. Mediterranean Journal of Social Sciences, 5(8), 465-473.

Green, D. (1994). What is quality in higher education? Great Britain: Society for Research into Higher Education \& Open University Press.

Green, P. (2014). Measuring Service Quality in Higher Education: A South African Case Study. International Education Research, 10(2). https://doi.org/10.19030/jier.v10i2.8515

In'airat, M. H., \& Al-Kassem, A. H. (2014). Total Quality Management in Higher Education: A Review. International Journal of Human Resource Studies, 4(3), 294-307. https://doi.org/10.5296/ijhrs.v4i3.6368

International Statistical Institute (ISI). (2017). Developing Countries. Retrieved from https://www.isi-web.org/index.php/resources/developing-countries

Khodayari, B., \& Khodayari, F. (2011). Service Quality in Higher Education. Case study: Measuring service quality of Islamic Azad University, Firoozkooh branch. Interdisciplinary Journal of Research in Business, 1(9). Retrieved from http://journaldatabase.info.info/articles/service_quality_higher_education_case.html

Manola, B., \& Tsarouhas, P. (2010). Implementing Total Quality Management Systems in Educational Organizations. Case Study: Academic Administration of Department of Logistics of ATEIH. In D. Aidonis, I. Manikas, \& D. Folinas (Eds.), Proceedings of the 2010 International Conference in Logistics (pp. 1-17). Katerini, Greece: Alexander Technological Educational Institute of Thessaloniki- Branch of Katerini. 
Nadim, Z. S., \& Al-Hinai, A. H. (2016). Critical Success Factors of TQM in Higher Education Institutions. International Journal of Applied Sciences and Management, 1(2). Retrieved from https://www.waljatcollege.edu.om/journal/archive-2016.html

Noaman, A. Y., Ragab, A. H. M., Fayoumi, A. G., Khedra, A. M., \& Madbouly, A. I. (2013). HEQAM: A developed higher education quality assessment model. Paper presented at the 2013 Federated Conference Computer Science and Information Systems (FedCSIS), Krakow, Poland. Abstract retrieved from https://www.researchgate.net/publication/261321450_HEQAM_A_developed_higher_education_quality_as sessment_model

Nyaoga, R. B., Nyamwange, O., Onger, R. N., \& Ombati, T. O. (2010). Quality Management Practices in Kenyan Educational Institutions: The case of the University of Nairobi, African. Journal of Business \& $\begin{array}{llll}\text { Management } & \text { (AJBUMA), } & \text { Retrieved } & \text { from }\end{array}$ http://www.uonbi.ac.ke/conferences/aibuma/journal/paper2QualityManagementMagutu.pdf

Oluseye, O. O., Borishade, T. T., Adeniyi, S., \& Chinelo, E. I. (2014). An Empirical Analysis of Total Quality Management and Perceived Corporate Image in Higher Education Management. European Scientific Journal, 10(2). Retrieved from http://eujournal.org/index.php/esj/article/viewFile/3917/3708

Pushpa, L. (2016). Implementation of Total Quality Management in Higher Education Institutions. International Journal of Scientific Engineering and Research (IJSER), 1(5). Retrieved from http://www.ijser.in/archives/v4i5/IJSER15813.pdf

Randheer, K. (2015). Service Quality Performance Scale in Higher Education: Culture as a New Dimension. International Business Research, 8(3), 29-41. https://doi.org/10.5539/ibr.v8n3p29

Sharma, S. K., Gupta, S. V., \& Singh, R. (2014). Implementation of TQM for Improving Organizational Effectiveness. International Journal of Application or Innovation in Engineering \& Management (IJAIEM), 3(9). Retrieved from http://www.ijaiem.org/Volume3Issue9/IJAIEM-2014-09-17-32.pdf

Soomro, T. R., \& Ahmad, R. (2012). Quality in Higher Education: United Arab Emirates Perspective. Higher Education Studies, 2(4), 148-152. https://doi.org/10.5539/hes.v2n4p148

Stasiak-Betlejewska, R., Kaye, M., Dyason, M., Stachová, K., \& Urbancová, H. (2014). The services quality level assessment at the technical university using the Servqual method. Journal on Efficiency and Responsibility in Education and Science, 7(3-4), 53-58. https://doi.org/10.7160/eriesj.2014.070302

Svensson, C., Antony, J., Ba-Essa, M., Bakhsh, M., \& Albliwi, S. (2015). A Lean Six Sigma program in higher education. International Journal of Quality \& Reliability Management, 32(9), 951-969. https://doi.org/10.1108/IJQRM-09-2014-0141

Takalo, S. K., Abadi, A. R. N. S., Vesal, S. M., Mizaei, A., \& Nawaser, K. (2013). Fuzzy Failure Analysis: A New Approach to Service Quality Analysis in Higher Education Institutions. International Education Studies, 6(9), 93-106.

Tarí, J. J., \& Dick, G. (2016). Trends in quality management research in higher education institutions. Journal of ServiceTheory and Practice, 26(3), 273-296. https://doi.org/10.1108/JSTP-10-2014-0230

Taskov, N., \& Mitreva, E. (2015). The motivation and the efficient communication both are the essential pillar within the building of the TQM (total quality management) system within the Macedonian Higher Education Institutions. Procedia-Social and Behavioral Sciences, 180(2015), 227-234. https://doi.org/10.1016/j.sbspro.2015.02.109

Teeroovengadum, V., Kamalanabhan, T. J., \& Seebaluck, A. K. (2016). Measuring service quality in higher education. Quality Assurance in Education, 24(2), 244-258. https://doi.org/10.1108/QAE-06-2014-0028

Todorut, A. V. (2013). The need of Total Quality Management in higher education. Procedia-Social and Behavioral Sciences, 83(2013), 1105-1110. https://doi.org/10.1016/j.sbspro.2013.06.207

Tsinidou, M., Gerogiannis, V., \& Fitsilis, P. (2010). Evaluation of the factors that determine quality in higher education: An empirical study. Quality Assurance in Education, 18(3), 227-244. https://doi.org/10.1108/09684881011058669

Twaissi, N. M., \& Al-Kilani, M. H. (2015). The Impact of Perceived Service Quality on Students' Intentions in Higher Education in a Jordanian Govermental University. International Business Research, 8(5), 81-92. https://doi.org/10.5539/ibr.v8n5p81 
Yalcin, M. A. (2012). Communication barriers in quality process: Sakarya University sample. The Turkish Online Journal of Educational Technology, 11(4). Retrieved from http://files.eric.ed.gov/fulltext/EJ989256.pdf

Yarahmadi, F., \& Magd, H. A. (2016). Factors Affecting the Readiness of Higher Education Institutions' Environment for the Establishment of TQM in Oman. Paper presented at the Twentieth International Conference on ISO and TQM, Oman. Abstract retrieved March 17, 2017, from http://www.hk5sa.com/icit/6.5 Oman-Farzaneh.pdf

Zabadi, A. M. (2013). Implementing Total Quality Management (TQM) on the higher education institutions: A conceptual model. Journal of Finance \& Economics, 1(1), 42-60. https://doi.org/10.12735/jfe.v1i1p42

Zafiropoulos, C., \& Vrana, V. (2008). Service quality assessment in a Greek higher education institute. Journal of business economics and management, $9(1), 33-45$. https://doi.org/10.3846/1611-1699.2008.9.33-45

Zakuan, N., Muniandy, S., Saman, M. Z. M., Ariff, M. S. M., Sulaiman, S., \& Jalil, R. A. (2012). Critical Success Factors of Total Quality Management Implementation in Higher Education Institution: A Review. International Journal of Academic Research in Businessand Social Sciences, 2(12). Retrieved from http://www.hrmars.com/admin/pics/1341.pdf

\section{Copyrights}

Copyright for this article is retained by the author(s), with first publication rights granted to the journal.

This is an open-access article distributed under the terms and conditions of the Creative Commons Attribution license (http://creativecommons.org/licenses/by/4.0/). 